\title{
KETIKA INDONESIA \\ INGIN MENJADI PUSAT KEUANGAN SYARIAH DUNIA
}

\author{
Dian Handayani \\ Politeknik Keuangan Negara STAN \\ dihandayani@pknstan.ac.id
}

\begin{abstract}
Islamic financial market in Indonesia is initiated by market-driven movements. Sukuk issuance is among of them. Growing market, not only domestic but also international, is one of the motivation in Sovereign Sukuk Law initiative. The success of Sukuk issuance has brought new ambitions to make Indonesia as Islamic financial hub in the world. This study aims to analyze the opportunities, challenges, advantages and disadvantages of Indonesia to become the world's Islamic financial center. The study is conducted based on what Malaysia has done - who claim to become a global hub of Islamic capital markets, and Britain which is a global financial center and set an ambitious agenda to become a global Islamic financial hub. This study uses descriptive analysis and SWOT analysis. As a result, Indonesia has a lot of potential but a more comprehensive strategy is needed to address the challenges in international financial markets.
\end{abstract}

Keywords: Islamic finance, Sukuk, Sovereign Sukuk, Islamic Financial Hub

\section{PENDAHULUAN}

Sukuk merupakan instrumen keuangan berbasis syariah yang telah menarik minat dunia internasional. Pelaku pasar keuangan menempatkan Sukuk sebagai instrumen keuangan untuk menarik dana Timur Tengah dan investor muslim. Rendahnya volatilitas pasar Sukuk dan imbal hasil yang menarik secara historis, telahmenarik minat berbagai investor tidak hanya investor muslim.Sukuk dianggap sebagai the new asset class dapat memberikan diversifikasi risiko.Beberapa negara mulai melakukan penerbitan Sukuk untuk menarik investor baru dan mendeklarasikan targetnya untuk menjadi global Islamic financial hub, pusat keuangan Islam. Di antara negara-negara tersebut adalah Malaysia yang saat ini menjadi negara dengan penerbitan Sukuk terbesar di dunia. Sedangkan dari negara barat ada Inggris yang telah lebih dulu dikenal sebagai pusat keuangan dunia. 
Inggris telah menjalani proses yang cukup lama untuk melegalkan penerbitan Sukuk dan menempatkan instrumen tersebut sama kompetitifnya dengan fixed instrument yang telah ada.Pemerintah Inggris sejak tahun 2007 telah mengumumkan minatnya untuk membuat instrumen Sukuk dapat menjadi pilihan instrumen yang menguntungkan. Pada tahun 2014 secara berturut-turut Pemerintah Inggris, Hong Kong, Afrika Selatan dan Luxembourg menerbitkan Sukuk sebagai instrumen pembiayaannya.

Di Indonesia, Sukuk pertama kali diterbitkan oleh PT. Indosatpada tahun 2002. Pemerintah Indonesia sendiri mulai menerbitkan Sukuk pada tahun 2008 setelah Undang-Undang No. 19 Tahun 2008 tentang Surat Berharga Syariah Negara (SBSN) ditetapkan pada 7 Mei 2008. SBSN atau disebut juga Sukuk Negara memperkaya alternatif instrumen pembiayaan APBN dan diterbitkan secara rutin setiap tahun di pasar domestik maupun pasar internasional. Per 2 Juni 2017 total outstanding Sukuk Negara telah mencapai Rp500 triliun. Indonesia juga telah dikenal sebagai negara terbesar dalam hal penerbitan Sukuk dalam denominasi USD di pasar internasional.Berkaca dari capaian tersebut dalam beberapa kesempatan Presiden Jokowi mengemukakan bahwa Indonesia harus mejadi pusat keuangan syariah dunia(Setkab, 2016). Hal tersebut didukung oleh besarnya potensi pasar keuangan syariah dari dalam negeri sendiri sebagai negara dengan penduduk Muslim terbesar di dunia.

Menjadi pusat keuangan syariah dunia telah menjadi ambisi beberapa negara tidak terkecuali Malaysia yang telah meluncurkan Capital Market Masterplan kedua yang memuat peran instrumen keuangan syariah secara terintegrasi dan lebih strategis, maupun negara-negara barat seperti Inggris dan Hongkong. Langkah yang dilakukan pemerintah negara-negara tersebut menarik untuk ditelaah lebih lanjut. Dengan mengkaji seberapa jauh upaya yang telah dilakukan oleh negara-negara tersebut, pemerintah Indonesia dapat menyusun rencana strategis sesuai keunggulan kompetitifnya untuk mewujudkan ambisinya sebagai pusat keuangan syariah dunia sebagaimana disampaikan Presiden Jokowi. Penelitian ini berusaha menyoroti dari satu aspek saja dalam industri keuangan syariah, yaitu Sukuk. 
Penelitian ini berusaha menjawab pertanyaan apakah Indonesia dapat menjadi pusat penerbitan Sukuk dunia melalui kajian mengenai apa yang telah dilakukan Malaysia dan Inggris untuk memenuhi mencapai ambisi menjadi pusat penerbitan Sukuk dunia, serta apa yang telah dicapai oleh Indonesia dalam penerbitan Sukuk. Penelitian ini bertujuan untuk menganalisis peluang, tantangan, kelebihan, dan kekurangan Indonesia untuk menjadi pusat Sukuk dunia berdasarkan apa yang telah dilakukan kedua negara tersebut.

Data yang digunakan dalam penelitian ini adalah data sekunder yang berasal dari berbagai literatur dan halaman daring untuk mengakses data terkini. Analisis untuk membandingkan apa yang telah dilakukan dan telah dicapai oleh yang telah menargetkan untuk menjadi global Islamic financial hub.Selain itu digunakan analisis SWOT untuk rtikel ini disusun sebagai berikut: bagian motif dan latar belakang penerbitan, langkah strategis pemerintah negara dalam penerbitan Sukuk; bagian menganalisis dan elanjutnya bagian kesimpulan.

\section{TELAAH LITERATUR DAN PENGEMBANGAN HIPOTESIS}

\section{Tinjauan Teori}

\section{Konsep Sukuk dan Perkembangannya di Era Modern}

Sukuk merupakan bentuk jamak dari Sakk yang berarti sertifikat. Sukuk sudah dikenal sejak awal peradaban Islam sebagai bentuk pembayaran yang dilakukan Pemerintah kepada para pegawai dan tentaranya. Pembayaran tersebut dilakukan dalam bentuk Sukukal-badaâ'i. Pemilik Sukuk dapat mencairkan Sukuk yang dimilikinya pada saat jatuh tempo untuk menerima sejumlah tertentu komoditas, biasanya gandum. Namun ada pula pemegang Sukuk yang menjualnya sebelum jatuh tempo (Haneef, 2009).

Di zaman modern, konsep surat berharga berbasis prinsip syariah yaitu Sukuk pertama kali kembali diperkenalkan dalam simposium ke-11 Islamic Development Bank tahun 2000 (Haneef, 2009). Accounting and Auditing Organization of Islamic Finance Institutions (AAOIFI) selanjutnya mendefinisikan Sukuk sebagaisertifikat yang merepresentasikan kepemilikan 
bersama yang tidak terpisahkan atas suatu aset berwujud, usufruct, jasa atau kepemilikan terhadap proyek tertentu atau aktivitas investasi tertentu. AAOIFI menyusun 14 kategori struktur Sukuk yang dapat diterbitkan. Bagi penerbit, pilihan struktur Sukuk perlu disesuaikan dengan beberapa faktorseperti karakteristik underlying asset dan target investor. Menurut Latham and Watkins LLP(2015), dari keempat belas jenis Sukuk dalam daftar AAOIFI, hanya tiga macam struktur yang marak digunakan saat ini yaitu ijara, murabaha, dan mudaraba-wakala.

Transaksi sukuk dimaksudkan untuk menjadi praktik terbaik (best practice) yang dapat direplika dalam industri keuangan syariah.Pengembangan struktur Sukuk yang diawali dari keinginan untuk menyasar dana investor muslim, cepat mendapat tempat di dunia keuangan internasional. Deutsche Bank sebagai salah satu investment bank terbesar di Eropa banyak mengembangkan struktur Sukuk maupun instrumen keuangan syariah lainnya yang merupakan replika dari instrumen keuangan konvensional (Irfan, 2014).Namun sesungguhnya ada perbedaan mendasar antara Sukuk dengan obligasi sebagaimana dikutip dari Iqbal \& Mirakhor (2007).Perbedaannya adalah bahwa obligasi merupakan surat pernyataan utang, sementara Sukuk mencerminkan sertifikat kepemilikan terhadap suatu underlying asset untuk periode tertentu dimana risiko dan kinerjanya diasosiasikan dari arus kas yang dihasilkan aset yang menjadi dasar penerbitan Sukuk tersebut (underlying asset), yang diteruskan kepada pemilik Sukuk (Abdullah et al., 2014).

\section{Penerbitan Sukuk oleh Pemerintah Malaysia}

Malaysia menganut dual legal system yaitu common law dan syariah. Perkembangan industri perbankan syariah di Malaysia dimulai secara bertahap sejak tahun 1983. Pemerintah Malaysia memberlakukan liberalisasi dalam mengembangkan pasar keuangan syariah di negaranya dengan cara pemberian izin kepada entitas asing untuk membuka praktek keuangan syariah di pasar domestik. Liberalisasi tersebut didukung dengan ditetapkannya Islamic Banking Act 1983, Takaful Act 1984, Banking and Financial Institutions Act 1989, Central Bank of 
Malaysia Act 1958 (Amendment 2009), dan Securities Commission Act 1993(Hasan, 2010).

Pemerintah Malaysia meluncurkan Sukuk pertamanya pada tahun 2002, dua tahun setelah konsep Sukuk modern pertama diluncurkan pada simposium Islamic Development Bank, satu tahun setelah Pemerintah Bahrain menerbitkan Sukuk pertama di pasar keuangan modern. Sukuk Pemerintah Malaysia cukup berhasil dari sisi kemampuannya memenuhi ketentuan penerbitan surat berharga di pasar keuangan internasional - suatu capaian yang tidak diperoleh Sukuk yang diterbitkan Pemerintah Bahrain. Sukuk senilai USD600 juta diterbitkan dengan struktur asset-backed yang didukung oleh aset Pemerintah senilai USD600 juta. Sukuk dengan tenor 5 tahun tersebut diterbitkan dengan format 144A/Reg. S, format yang biasa digunakan untuk penerbitan global bond di pasar keuangan internasional dan khusus menyasar high networth investor (Haneef, 2009).

Namun asset-backed Sukuk yang diterbitkan Pemerintah Malaysia tersebut menempatkannya termasuk dalam secured instrument. Karena Pemerintah Malaysia sebelumnya telah menerbitkan obligasi di pasar keuangan internasional yang bersifat unsecured instrument, penerbitan asset-backed Sukuk pada tahun 2002 tersebut terancam melanggar standard negative pledge yang berlaku untuk transaksi internasional. Asset-backed Sukuk menempatkan investornya memiliki hak yang lebih tinggi dibandingkan investor obligasi Malaysia yang telah terbit sebelumnya. Jalan keluar yang dilakukan Pemerintah Malaysia adalah menjadikannya unsecured instrument atau dengan kata lain menjadikannya assetbased Sukuk (Haneef, 2009).

Malaysia merupakan negara dengan penerbitan Sukuk terbesar. Capaian tersebut berkat dukungan politik yang kuat dan pimpinan tertinggi pemerintahan Malaysia. Berbagai peraturan disahkan untuk menempatkan instrumen keuangan syariah selevel dengan instrumen keuangan konvensional, seperti amandemen terhadap Undang-Undang Pajak memberikan tax neutrality untuk transaksi keuangan syariah sehingga dapat bersaing secara kompetitif dengan instrumen keuangan konvensional (Najeeb \& Vejzagic, 2013). 
Pada tahun 2011 Pemerintah Malaysia menerbitkan Capital Market Masterplan 2 yang memuat target pengembangan pasar modal Malaysia termasuk pasar modal syariah. Dari upaya yang telah dilakukan selama fase pertama pengembangan pasar modal Malaysia, negara tersebut telah memperoleh keuntungan strategis di mana mayoritas aset berupa aset keuangan syariah sehingga dapat menjangkau pasar yang lebih luas termasuk investor konvensional. Pangsa pasar yang lebih luas dan likuiditas telah menciptakan kekuatan tersendiri. Sementara itu produk dan jasa keuangan Islam juga diuntungkan dengan adanya kerangka perlindungan investor yang lebih luas serta jaminan konsistensi dan kejelasan dalam aspek kesesuaian syariah.

Target utama Pemerintah Malaysia adalah untuk menjadi global hub pasar modal syariah. Hal tersebut bisa jadi akan segera terwujud dengan telah diimplementasikannya infrastruktur hukum dan perdagangan yang dibutuhkan serta terstandarisasi. Pasar Sukuk memiliki potensi yang besar di pasar internasional. Malaysia sebagai pemimpin di pasar Sukuk global akan terus menciptakan terobosan untuk mencapai target sebagai global hub tersebut. Di antara terobosan tersebut, prioritas ditujukan pada Socially Responsible Investing (SRI) berdasarkan prinsip syariah (Securities Commission Malaysia, 2011).

Terlebih dulu dikenal sebagai ethical investing, perkembangan literatur membawa deskripsi Socially Responsible Investment (SRI) sebagai standar istilah yang digunakan. Salah satu yang mendorong perubahan tersebut adalah makin maraknya penggunaan prinsip-prinsip SRI oleh investor institusi, tidak lagi hanya investor individu. Namun pada prinsipnya, faktor financial returnlah yang membedakan antara SRI dengan amal (Sparkes, 2002). Perkembangan terkini juga membawa Sukuk sebagai instrumen keuangan yang cocok dengan SRI. Baik Sukuk maupun SRI menjadi area di bidang keuangan yang paling pesat perkembangannya (Bennet \& Iqbal, 2013; Marwan \& Adawiah, 2015).

SRI Sukuk menjadi salah satu fokus yang akan dikembangkan oleh Pemerintah Malaysia sesuai dengan Capital Market Masterplan 2. Penerbitan SRI Sukuk ditujukan untuk mendanai proyek-proyek yang memenuhi syarat dan bertujuan untuk melestarikan dan melindungi lingkungan serta sumber daya alam, 
menghemat penggunaan energi, mempromosikan penggunaan energi terbarukan, mengurangi emisi gas rumah kaca, atau meningkatkan kualitas hidup bagi masyarakat (Marwan \& Adawiah, 2015).

Dari milestone tersebut, terlihat bahwa Pemerintah Malaysia berupaya untuk tidak bergantung pada sentimen agama untuk memperkuat industri keuangan syariahnya. Government driven mendominasi diiringi dengan upaya kongkrit untuk menempatkan instrumen keuangan syariah seperti Sukuk sejajar dengan standar internasional yang telah lebih dulu berkembang dan diakui seperti SRI.

\section{Penerbitan Sukuk oleh Pemerintah Inggris}

Walaupun mayoritas penduduk Inggris merupakan non Muslim, namun sejak tahun 1980-an praktek keuangan syariah di Inggris sudah hadir dalam bentuk penawaran produk dan jasa keuangan syariah kepada pasar wholesale. Salah satu jasa keuangan yang ditawarkan adalah transaksi commodity murabaha. Untuk pasar ritel, produk dan jasa keuangan syariah mulai ditawarkan pada tahun 1990-an dalam bentuk pembiayaan untuk kepemilikan rumah. Walaupun berkembang secara lambat sejak tahun 1980-an, namun pada awal tahun 2000 mulai terjadi progres yang signifikan berkat dukungan otoritas pemerintahan dan keuangan. Pada tahun 2006 Prime Minister Gordon Brown dalam konferensi yang diselenggarakan oleh Muslim Council of Britain menegaskan kepada publik untuk menjadikan Inggris sebagai pintu gerbang untuk perdagangan dan keuangan Islam. Untuk ituotoritas Inggris telah melakukan serangkaian perubahan terhadap ketentuan perpajakan dan legislatifnya untuk menjadikan Inggris sebagai global Islamic financial hub (Nizami, 2011).

Sebelumnya, perdebatan mengenai penerapan prinsip keuangan syariah dalam sistem perundangan Inggris telah menjadi diskusi hangat karena Inggris menganut sistem hukum sekuler. Pemerintah Inggris akhirnya memutuskan untuk mengasimilasi sistem keuangan syariah dalam tata hukumnya, bukan menganut dual regulatory system seperti yang banyak dilakukan oleh beberapa negara ketika ingin mengimplementasikan sistem keuangan syariah dalam kehidupan bernegaranya. Hal ini sejalan dengan kebijakan sekuler yang dianut Pemerintah 
Inggris untuk memisahkan hukum dengan agama. Sebagai konsekuensi kebijakan yang diambil oleh Pemerintah Inggris tersebut, sistem keuangan syariah diperlakukan setara dengan sistem keuangan konvensional tanpa memberikan insentif apapun, sekaligus tanpa menimbulkan diskriminasi (Asmat, 2014).

Hasilnya, Undang-Undang Keuangan (Finance Acts) Tahun 2005 dan 2006 disahkan memuat ketentuan perpajakan yang ditujukan agar produk-produk keuangan Islam dikenakan perlakuan pajak yang sama dengan produk keuangan konvensional. Undang-Undang Keuangan Tahun 2007 memberikan penegasan secara spesifik terhadap instrumen Sukuk (Ainley et al, 2007).

Penerbitan Sukuk oleh Pemerintah Inggris pada 2014 menempatkan Inggris sebagai negara barat pertama yang melakukan penerbitan instrumen berbasis syariah tersebut. Sukuk senilai GBP200jutatersebut ditawarkan dengan tenor 5 tahun dan tingkat imbalan 2,036\% per tahun. Debut penawarannya telah menarik permintaan hingga GBP2,3 miliar. Investor berasal dari Ingris, Timur Tengah dan Asia yang terdiri dari sovereign wealth funds, bank sentral serta institusi keuangan domestik dan internasional.Namun sebelum penerbitan perdana Sukuk oleh Pemerintah Inggris tersebut, London Stock Exchange telah menjadi tempat bagi perdagangan sekunder instrumen Sukuk. Per akhir 2016 tercatat 65 penerbitan dengan total nilai USD48 miliar di bursa Inggris tersebut. Selain itu terdapat lebih dari 100.000 konsumer ritel dengan nilai bersih dana yang dikelola dengan prinsip keuangan Islam (Islamic funds) mencapai USD600 juta (London Stock Exchange, 2017).

Segera setelah hasil referendum yang menyatakan keluarnya Inggris dari Uni Eropa, muncul berbagai spekulasi mengenai keberlangsungan komitmen Inggris untuk menjadi global Islamic financial hub. Pandangan positif mewarnai spekulasi tersebut mengingat Inggris telah memiliki jaringan yang kuat secara komersial dengan negara-negara non EU di Asia, Afrika dan wilayah lainnya (Jaffer, 2016). Pendapat yang agak kritis tertuju pada kemampuan praktek keuangan Islam di Inggris yang selama ini diuntungkan dari kemampuannya terhindar dari exposurekrisis keuangan global dan semakin tingginya minat dunia terhadap instrumen baru ini. Namun setelah Brexit,dibutuhkan fundamental yang 
lebih kuat untuk menikmati keuntungan dari praktek keuangan syariah, yaitu pertimbangan komersial dan infrastruktur hukum yang kuat (Follan, 2016).

Penegasan datang dari official London Stock Exchange sebagaimana dikutip oleh gulf timesbahwa paska Brexit, London tetap akan menjadi pusat keuangan Islam di negara barat dan tetap akan menjadi yang terdepan dalam perkembangan keuangan Islam di wilayah Eropa(Maierbrugger, 2017). Hal tersebut didasarkan pada keunggulan yang telah dimiliki oleh Inggris terkait pasar keuangan. Walaupun Amerika dan Jepang menjadi pasar utang terbesar di dunia, namun Inggris memiliki pangsa pasar terbesar untuk instrumen utang internasional yang diterbitkan perusahaandan negara selain Inggris.Menurut data London Stock Exchange per September 2016, kapitalisasi pasarnya telah mencapai GBP4,4 triliun, menempatkan London Stock Exchange sebagai bursa terbesar di Eropa dan internasional, dengan jumlah perusahaan yang tercatat hampir mencapai 2.300 perusahaan dari 60 negara. Sebagai bukti tidak tertinggalnya Inggris dari inovasi terkini, penerbitan perdana green bonds berdenominasi RMB dan INR dilakukan di Inggris. Dengan segala capaian, keahlian, dan keunggulan yang dimiliki, Inggris memiliki seluruh infrastruktur yang diperlukan untuk meluncurkan green finance sector (City of London Corporation, 2016).

Inggris sebagai negara maju mengakui popularitas Sukuk sebagai instrumen keuangan syariah berupaya untuk mempertahankan posisi London sebagai pusat keuangan dunia dengan menyediakan jasa keuangan syariah di negara tersebut. Motif keuntungan yang mewarnai latar belakang tersebut dihadapkan pada tantangan dampak komersial dan kebutuhan infrastruktur hukum yang lebih kuat ketika negara tersebut memutuskan keluar dari Uni Eropa.

\section{METODE PENELITIAN DAN PEMBAHASAN}

Penelitian ini merupakan penelitian kualitatif dengan menggunakan data sekunder yang berasal dari berbagai literatur dan halaman daring untuk mengakses data dan informasi terkini. Analisis deskriptif digunakan untuk membandingkan dengan Indonesia, apa yang telah dilakukan dan dicapai oleh 
Malaysia dan Inggris yang telah menargetkan untuk menjadi global Islamic financial hub. Perbandingan dengan negara Malaysia dan Inggris dipilih karena Malaysia merupakan negara dengan penduduk mayoritas Muslim dan termasuk negara pertama yang menerbitkan Sukuk di era modern. Selain itu perkembangan pasar Sukuk di Malaysia menarik untuk dipelajari mengingat di negara tersebut volume penerbitan Sukuk terbesar di dunia. London merupakan pusat keuangan dunia dan menjadi tempat lahirnya sistem keuangan modern. Dipilihnya Inggris mewakili negara barat dan sebagai pusat keuangan dunia yang tidak ingin tertinggal dari perkembangan instrumen keuangan syariah ini. Tidak terhitung pernyataan dari pejabat pemerintahan Inggris yang dikeluarkan untuk menegaskan ambisinya menjadi pusat keuangan syariah. Selanjutnya analisis SWOT dilakukan untuk mengkaji peluang, tantangan, kelebihan, dan kekurangan yang dimiliki Indonesia untuk mewujudkan Indonesia sebagai pusat Sukuk dunia.

\section{HASIL PENELITIAN DAN PEMBAHASAN}

\section{Hasil}

\section{Penerbitan Sukuk oleh Pemerintah Indonesia}

Trend sukuk dunia pun turut menarik Pemerintah Indonesia. Pasar Surat Berharga Negara (SBN) di Indonesia baru terbentuk pada akhir tahun 2000 ketika bank rekap mulai memperdagangkan surat utang negara yang berasal dari obligasi rekap dalam rangka penyelamatan sistem perbankan akibat krisis 1998. Walau masih dalam jumlah yang sangat kecil, perdagangan obligasi rekap mulai dilakukan antar investor, baik dengan bank sesama penerima rekap, bank yang tidak menerima rekap, maupun investor asing. Perdagangan tersebut mendorong tumbuhnya pasar surat berharga dalam sistem pasar keuangan di Indonesia (Waluyanto, 2009).

Pada tahun 2002 setelah disahkannya Undang-Undang No. 24 Tahun 2002 tentang Surat Utang Negara (UU SUN), Pemerintah Indonesia baru secara aktif menggunakan instrumen SBN sebagai instrumen pembiayaan.Walaupun UU SUN telah memberikan landasan yang cukup mengenai tujuan penerbitan, bentuk dan jenis instrumen, kewenangan dan kewajiban Pemerintah terkait penerbitan SUN, 
namun hal tersebut tidak cukup memberikan landasan hukum bagi penerbitan instrumen keuangan yang berlandaskan prinsip syariah. Terdapat aspek-aspek yang membutuhkan pengaturan khusus seperti penggunaan underlying asset serta kelengkapan infrastruktur organisasi seperti pembentukan SPV. Oleh karena itu Pemerintah mengusulkan Rancangan Undang-Undang Surat Berharga Syariah Negara (RUU SBSN) untuk meletakkan landasan hukum yang kuat bagi tata kelolapenerbitan SBSN (Waluyanto, 2009).

Dalam naskah akademis RUU SBSN tersebut diuraikan mengenai besarnya potensi permintaan Sukuk di pasar keuangan internasional khususnya dana repatriasi dari Timur Tengah. Namun, masih terbatasnya kapasitas Indonesia untuk menyerap dana tersebut disebabkan kurangnya instrumen investasi yang tersedia menyebabkan Indonesia dapat kehilangan momentum tersebut.Naskah akademis RUU SBSN juga menyoroti perlunya Pemerintah ikut aktif dalam pasar keuangan syariah dalam negeri untuk mendorong industri tersebut berkembang secara optimal. Lebih lanjut,momentum yang ada juga hendak dimanfaatkan untuk memperluas alternatif pembiayaan negara, khususnya instrumen berbasis syariah untuk memobilisasi dana publik secara luas dan efisien. Setelah UndangUndang SBSN No. 19 Tahun 2008 disahkan pada 7 Mei 2008, Pemerintah melakukan penerbitan perdana pada 26 Agustus 2008 dengan volume penerbitan Rp4,8 triliun. Per 2 Juni 2017, total outstanding Sukuk Negara telah mencapai Rp500 triliun.

Sesuai sasaran penerbitan Sukuk Negara sebagaimana diungkapkan dalam Naskah Akademis RUU SBSN, terlihat Pemerintah cukup berhasil mencapai tujuannya. Dari penerbitan Global Sukuk di pasar internasional, investor Islam dan Timur Tengah terus memburu instrumen yang dikeluarkan Pemerintah Indonesia sebagaimana dapat dilihat pada Tabel 1. Indonesia juga menempati posisi pertama negara dengan penerbitan Sukuk dalam USD di pasar internasional terbesar dengan total penerbitan USD10,15 juta sebagaimana dapat dilihat pada Grafik 1. Capaian Indonesia di pasar keuangan syariah ini juga yang berusaha dioptimalkan melalui upaya Indonesia bersama Turki dan Islamic Development Bank untuk mendirikan World Islamic Infrastructure Bank (Nangoy, 2016). 
Tabel 4.1

Alokasi Investor Timur Tengah dan Islam

dalam Penerbitan Global Sukuk

\begin{tabular}{|c|c|c|c|c|c|c|c|c|}
\hline & $\mathbf{2 0 0 9}$ & $\mathbf{2 0 1 1}$ & $\mathbf{2 0 1 2}$ & $\mathbf{2 0 1 3}$ & $\mathbf{2 0 1 4}$ & $\mathbf{2 0 1 5}$ & $\mathbf{2 0 1 6}$ & $\mathbf{2 0 1 7}$ \\
\hline $\begin{array}{c}\text { Volume } \\
\text { Penerbitan }\end{array}$ & $\begin{array}{c}\text { USD65 } \\
0 \text { juta }\end{array}$ & $\begin{array}{c}\text { USD1 } \\
\text { miliar }\end{array}$ & $\begin{array}{c}\text { USD1 } \\
\text { miliar }\end{array}$ & $\begin{array}{c}\text { USD1,5 } \\
\text { miliar }\end{array}$ & $\begin{array}{c}\text { USD1,5 } \\
\text { miliar }\end{array}$ & $\begin{array}{c}\text { USD2 } \\
\text { miliar }\end{array}$ & $\begin{array}{c}\text { USD750 juta } \\
\mid \text { USD1,75 } \\
\text { miliar }\end{array}$ & $\begin{array}{c}\text { USD1 } \\
\text { miliar } \mid \\
\text { USD2 } \\
\text { miliar }\end{array}$ \\
\hline Indonesia & $8 \%$ & $12 \%$ & $20 \%$ & $15 \%$ & $10 \%$ & $10 \%$ & $10 \% \mid 10 \%$ & $\begin{array}{c}10 \% \mid \\
10 \%\end{array}$ \\
\hline $\begin{array}{c}\text { Timur } \\
\text { Tengah }\end{array}$ & $30 \%$ & $30 \%$ & $30 \%$ & $20 \%$ & $35 \%$ & $41 \%$ & $42 \% \mid 28 \%$ & $27 \% \mid$ \\
\hline Uslam & $19 \%$ & $8 \%$ & $12 \%$ & $24 \%$ & $20 \%$ & $21 \%$ & $2 \% \mid 15 \%$ & $21 \% \mid$ \\
\hline Eropa & $11 \%$ & $18 \%$ & $15 \%$ & $16 \%$ & $15 \%$ & $16 \%$ & $15 \% \mid 22 \%$ & $14 \% \mid 9 \%$ \\
\hline Other Asia & $32 \%$ & $32 \%$ & $23 \%$ & $25 \%$ & $20 \%$ & $12 \%$ & $31 \% \mid 25 \%$ & $28 \% \mid$ \\
\hline
\end{tabular}

Sumber: Direktorat Pembiayaan Syariah, DJPPR, diolah.

\section{Grafik 4.1}

Indonesia sebagai Negara terbesar dalam hal total Penerbitan Sukuk dalam USD di Pasar Internasional (24 Februari 2017)

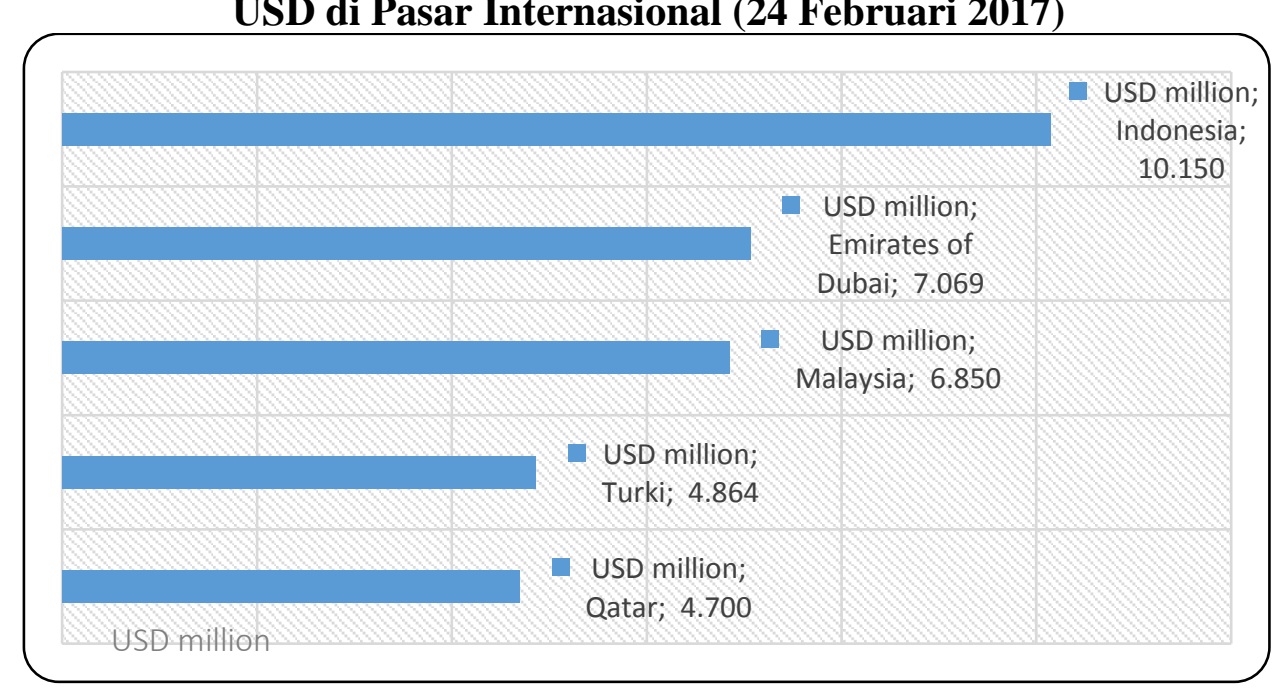

Sumber: Direktorat Pembiayaan Syariah, DJPPR, diolah.

Selanjutnya, Naskah Akademis juga mengemukakan argumentasi mengenai pentingnya RUU SBSN diberlakukan untuk memperluas basis pembiayaan negara. Dalam hal ini sekali lagi Pemerintah terlihat cukup sukses, terlihat dari 
terus bertambahnya proporsi volume penerbitan Sukuk Negara terhadap total penerbitan SBN setiap tahunnya seperti dapat dilihat pada Grafik 2.

\section{Grafik 4.2}

Penerbitan Sukuk Negara dibandingkan SBN (bruto) 2008 - 2016 (Rp triliun)

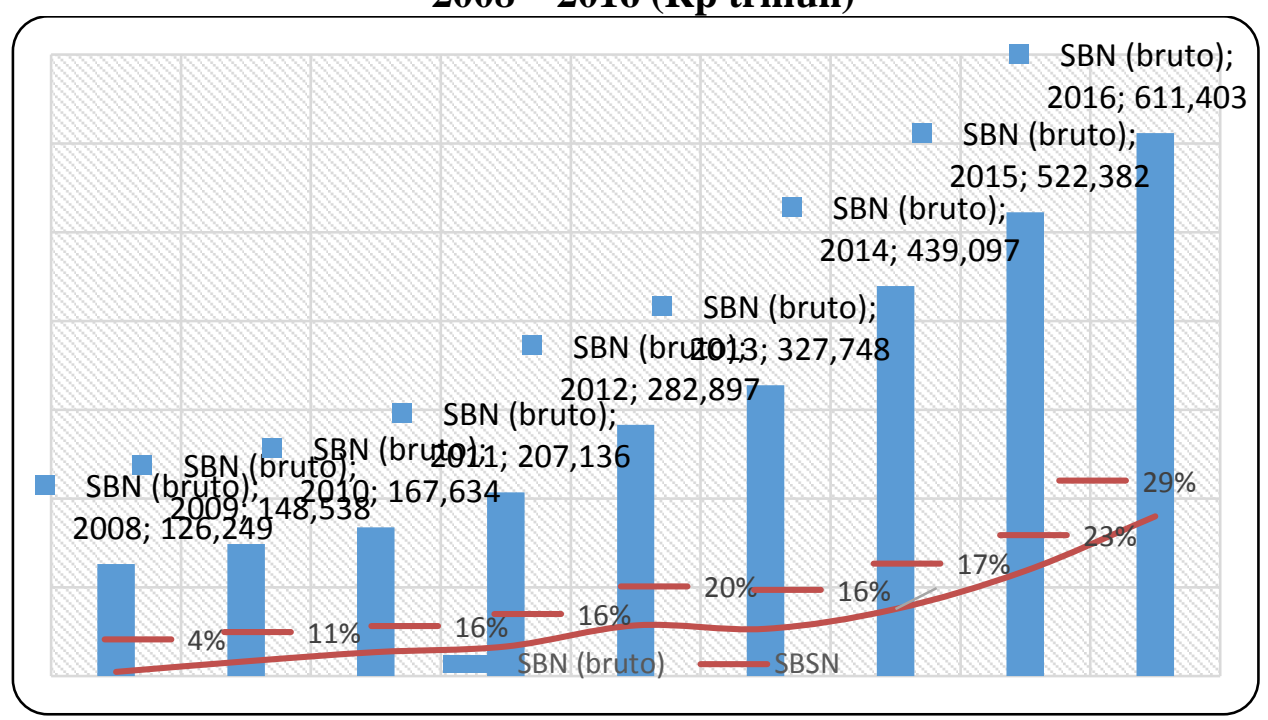

Sumber: Direktorat Jenderal Pengelolaan Pembiayaan dan Risiko, Kementerian Keuangan, diolah

Sebagai basis pembiayaan negara, pemerintah juga berusaha menyasar pasar ritel dengan menawarkan instrumen investasi berbasis syariah yang aman dan menguntungkan. Sukuk Ritel yang mulai diterbitkan tahun 2009 adalah instrumen yang khusus ditujukan untuk investor WNI. Keberhasilan Sukuk Ritel menarik jumlah investor setiap tahunnya sebagaimana dapat dilihat pada Grafik 3, menunjukkan besarnya potensi pasar ritel di Indonesia. Potensi pasar ritel inilah yang dicapai dalam rangka pendalaman pasar ketika Kementerian Keuangan bersama Bursa Efek Indonesia (BEI) dan Otoritas Jasa Keuangan (OJK) meluncurkan electronic trading platform (ETP) untuk Obligasi Ritel Indonesia (ORI) pada awal tahun 2017 (Audriene, 2017). 


\section{Grafik 4.3}

Total Penerbitan dan Jumlah Investor

Sukuk Ritel Tahun 2009-2016

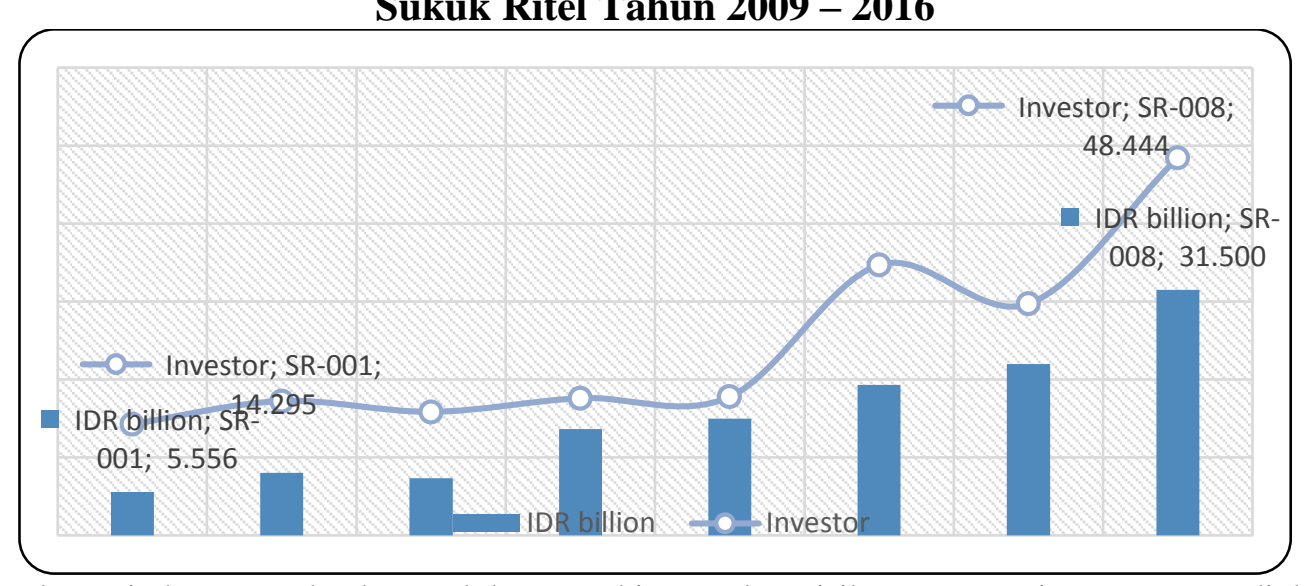

Sumber: Direktorat Jenderal Pengelolaan Pembiayaan dan Risiko, Kementerian Keuangan, diolah

Dalam hal tujuan penerbitan Sukuk Negara, Pasal 4 UU SBSN No. 19 Tahun 2008 memuat tujuan penerbitan Sukuk Negara yaitu untuk pembiayaan APBN termasuk pembiayaan proyek.Hal ini diwujudkan dengan ditetapkannya Peraturan Pemerintah No. 56 tahun 2011 tentang Pembiayaan Proyek Melalui Penerbitan SBSN. Sesuai PP tersebut,diwujudkan suatu skema dimana proyek tertentu yang diinisiasi oleh kementerian teknis dapat dibiayai dengan penerbitan Sukuk Negara melalui skema APBN. Skema earmarkedhasil penerbitan SBSN dengan pembiayaan proyek tertentu tersebut selanjutnya dikenal dengan skema Project Financing Sukuk(Direktorat Pembiayaan Syariah, 2015).

Selanjutnya dengan dukungan Fatwa DSN-MUI No. 76/DSNMUI/VI/2010tentang SBSN Ijarah Asset to be Leaseddan Ketetapan DSN-MUI No. 1 tahun 2012tentang Kriteria Proyek Sesuai Dengan Prinsip Syariah, pada tahun 2012 proyek pertamadiusulkan melalui Bappenas.Proyek yang diusulkan oleh Kementerian Perhubungan tersebut selanjutnya dimintakan persetujuan ke DPR untuk dapat dibiayai dalam APBN 2013. Pembiayaan proyek dengan skema Project Financing Sukuk mulai dilaksanakan pada tahun 2013 untuk proyek pembangunan jalur ganda Cirebon - Kroya senilai Rp800 miliar.Selain akad 
Ijarah Asset to be Leased, pada tahun 2014 telah diterbitkan Fatwa DSN-MUI No. 95/DSN-MUI/VII/2014 tentang SBSN Wakalah yang juga dapat digunakan sebagai struktur akad Sukuk Negara untuk pembiayaan proyek. Selanjutnya nilai dan jumlah proyek yang dibiayai dengan skema Project Financing Sukukterus mengalami peningkatan setiap tahunnya sebagaimana dapat dilihat pada Tabel 4.2 .

Tabel 4.2

Proyek yang dibiayai dengan skema Project Financing Sukuk

\begin{tabular}{|c|c|c|c|c|}
\hline 2013 & 2014 & 2015 & 2016 & 2017 \\
\hline Rp800 miliar & Rp1,5 triliun & Rp7,1 triliun & $\begin{array}{c}\text { Rp13,67 } \\
\text { triliun }\end{array}$ & $\begin{array}{c}\text { Rp16,76 } \\
\text { triliun }\end{array}$ \\
\hline $\begin{array}{l}\text { Jalur ganda } \\
\text { KA Cirebon - } \\
\text { Kroya di } \\
\text { bawah } \\
\text { Kementerian } \\
\text { Perhubungan. }\end{array}$ & $\begin{array}{l}\text { Jalur ganda } \\
\text { KA Cirebon - } \\
\text { Kroya di } \\
\text { bawah } \\
\text { Kementerian } \\
\text { Perhubungan } \\
\text { (lanjutan). }\end{array}$ & $\begin{array}{l}\text { Jalur KA di } \\
\text { Jakarta, Jawa } \\
\text { Tengah, } \\
\text { Sumatra, di } \\
\text { bawah } \\
\text { Kementerian } \\
\text { Perhubungan. }\end{array}$ & $\begin{array}{l}\text { Jalur KA di } \\
\text { Jakarta, Jawa } \\
\text { Tengah, } \\
\text { Sumatra, di } \\
\text { bawah } \\
\text { Kementerian } \\
\text { Perhubungan. }\end{array}$ & $\begin{array}{l}\text { Jalur ganda } \\
\text { dan laying di } \\
\text { Jawa, } \\
\text { Sumatera, } \\
\text { Sulawesi, di } \\
\text { bawah } \\
\text { Kementerian } \\
\text { Perhubungan. }\end{array}$ \\
\hline & $\begin{array}{l}\text { Jalur ganda } \\
\text { KA } \\
\text { Manggarai - } \\
\text { Jatinegara di } \\
\text { bawah } \\
\text { Kementerian } \\
\text { Perhubungan. }\end{array}$ & $\begin{array}{l}\text { Jalan dan } \\
\text { jembatan } \\
\text { Propinsi di } \\
\text { bawah } \\
\text { Kementerian } \\
\text { Pekerjaan } \\
\text { Umum. }\end{array}$ & $\begin{array}{l}\text { Jalan dan } \\
\text { jembatan } \\
\text { Propinsi di } \\
\text { bawah } \\
\text { Kementerian } \\
\text { Pekerjaan } \\
\text { Umum. }\end{array}$ & $\begin{array}{l}\text { Jalan dan } \\
\text { jembatan } \\
\text { Propinsi di } \\
\text { bawah } \\
\text { Kementerian } \\
\text { Pekerjaan } \\
\text { Umum. }\end{array}$ \\
\hline & $\begin{array}{l}\text { Asrama Haji } \\
\text { di bawah } \\
\text { Kementerian } \\
\text { Agama. }\end{array}$ & $\begin{array}{l}\text { Infrastruktur } \\
\text { pendidikan } \\
\text { tinggi dan } \\
\text { Kantor } \\
\text { Urusan }\end{array}$ & $\begin{array}{l}\text { Infrastruktur } \\
\text { pendidikan } \\
\text { tinggi dan } \\
\text { Kantor } \\
\text { Urusan }\end{array}$ & $\begin{array}{l}\text { Infrastruktur } \\
\text { pendidikan } \\
\text { tinggi dan } \\
\text { Kantor } \\
\text { Urusan }\end{array}$ \\
\hline
\end{tabular}




\begin{tabular}{|l|l|l|l|l|}
\hline & & Agama di & Agama di & Agama di \\
& bawah & bawah & bawah \\
Kementerian & Kementerian & Kementerian \\
& & Agama. & Agama & Agama \\
\hline & & & $\begin{array}{l}\text { Infrastruktur } \\
\text { pengendali } \\
\text { banjir. }\end{array}$ \\
\hline
\end{tabular}

Sumber: Direktorat Jenderal Pengelolaan Pembiayaan dan Risiko, Kementerian Keuangan.

Dibandingkan negara tetangga Malaysia, industri keuangan syariah di Indonesia tergolong industri yang baru lahir. Tingkat pertumbuhan yang lambat diduga akibat respon otoritas yang kurang cepat untuk mendorong diterapkannya berbagai aturan pendukung. Menurut Global Islamic Finance Forum Report 2012, regulasi keuangan Islam di Indonesia disusun berdasarkan evaluasi kasus per kasus. Hal ini berbeda dengan model Pemerintah Malaysia di mana pemerintahnya mengambil peran pro-aktif. Beberapa tantangan yang dihadapi Indonesia adalah agak terlambatnya pemerintah Indonesia memasuki industri keuangan syariah di mana beberapa negara lain sudah mulai mempersiapkan dan memiliki yurisdiksi yang mapan untuk implementasi keuangan syariah di negaranya. Namun Indonesia memiliki keunggulan dari besarnya jumlah penduduk Muslim. Terkait dengan hal tersebut, dengan dukungan yang kuat dari otoritas, Indonesia memiliki kesempatan yang besar untuk menjadi Islamic finance hub (Najeeb \& Vejzagic, 2013).

Di lain sisi, walaupun penerbitan Sukuk perdana di Indonesia dilakukan oleh korporasi namun perkembangan Sukuk korporasi tidak secepat instrumen Sukuk Negara. Per 9 Juni 2017 total emisi Sukuk korporasi hanya sebesar Rp23,13triliun dengan outstanding Rp14,85 triliun. Pada tahun 2015 OJK meluncurkan peraturan tentang penerbitan dan persyaratan Sukuk melalui POJK No. 18/POJK.04/2015 tanggal 10 November 2015. Peraturan tersebut diklaim telah menyederhanakan proses penerbitan Sukuk dalam hal dokumen pendaftaran bagi emiten dan memperkuat perlindungan kepada investor dalam bentuk diwajibkannya emiten menyusun perjanjian perwaliamanatan sukuk. 
Upaya menyatukan otoritas di Indonesia untuk mewujudkan strategi yang komprehensif baru terwujud pada akhir 2015 di mana Bappenas selaku Koordinator Tim Penyusun Lintas Regulator menerbitkan Masterplan Arsitektur Keuangan Syariah. Dokumen yang disusun dengan melibatkan OJK, Bank Indonesia, dan Kementerian Keuangan tersebut memuat rekomendasi langkah pengembangan sistem keuangan syariah nasional secara sistematis dan terukur. Sebagai langkah kongkrit untuk mewujudkan Masterplan tersebut, sudah diterbitkan Perpres No. 91 Tahun 2016 tentang Komite Nasional Keuangan Syariah.

Rencana masa depan pasar Sukuk di Indonesia termuat dalam Masterplan tersebut. Diakui bahwa pasar Sukuk saat ini bergantung pada Sukuk Negara yang diterbitkan Pemerintah. Khusus untuk Sukuk Negara, direkomendasikan untuk meningkatkan nominal penerbitan Sukuk Negara terhadap Surat Utang Negara sebagai instrumen pembiayaan APBN hingga 50\%. Untuk menciptakan permintaan, BUMN dan entitas investasi pemerintah seperti dana pensiun akan diminta untuk meningkatkan portofolio mereka dalam Sukuk Negara.

Kurang berkembangnya Sukuk korporasi juga menimbukan keprihatinan sehingga akan diciptakan skema penjaminan Pemerintah untuk Sukuk yang diterbitkan BUMN dan proyek infrastruktur demi menambah keyakinan investor. Rekomendasi lain diantaranya meliputi peluncuran instrumen baru yang meliputi program sukuk untuk pembiayaan infrastruktur yang menyasar investor institusi termasuk lembaga asing serta investor ritel; serta peningkatan infrastruktur pasar seperti pemberlakuan sistem Dealer Utama, peluncuran Reksa Dana Sukuk yang meliputi portofolio Sukuk pemerintah, BUMN, dan korporasi, serta pembentukan Mega Sukuk Fund berupa dana nasional dalam jumlah besar yang berfungsi sebagai market maker di pasar sekunder Sukuk. Direkomendasikan pula pemberian insentif pajak secara terbatas, perubahan perlakuan akuntansi Sukuk, serta peningkatan kesadaran masyarakat melalui edukasi yang terarah (Bappenas, 2015). 


\section{Analisis SWOT Indonesia sebagai Pusat Sukuk Dunia}

Analisis ini dimaksudkan untuk mengidentifikasi peluang, tantangan, kelebihan, dan kekurangan yang dimiliki Indonesia untuk menjadi pusat Sukuk dunia. Adapun yang dimaksud dengan pusat keuangan menurut kriteria geografis adalah tempat yang menjadi pusat konsentrasi fungsi jasa keuangan. Karena kompleksnya jasa keuangan yang disediakan, maka biasanya pusat keuangan berupa kota besar. Adanya pusat keuanganpenting untuk meningkatkan efisiensi transaksi baik bagi korporasi maupun individu di pasar internasional.Ukuran suatu kota dapat dianggap sebagai pusat keuangan dapat terlihat dari tenaga kerja di sektor keuangan, jumlah aset institusi keuangan, turnovernilai saham di bursa, jumlah komunikasi yang dilakukan melalui media elektronik, juga kehadiran bank asing serta kantor pusat dari perusahaan multinasional sektor non keuangan. Semua itu dapat diukur melalui composite financial centre index atau FINDEX (Wang, Zhao, \& Wang, 2007).

Tabel 3 memuat hasil analisis SWOT posisi Indonesia sebagai pusat Sukuk dunia berdasarkan uraian pada bab-bab sebelumnya.Analisis SWOT mengidentifikasi faktor internal dan faktor eksternal yang dimiliki Indonesia. Faktor internal terdiri dari strengthdan weakness. Strengthberupa keunggulan sumber daya yang dimiliki yang dapat secara efektif digunakan untuk mencapai tujuan. Weakness yaitu keterbatasan yang mempersulit pencapaian tujuan. Sedangkan faktor eksternal terdiri dari opportunities dan threats. Opportunities yaitu keunggulan di pasar yang menempatkannya dalam situasi yang menguntungkan. Sedangkan threats yaitu posisi yang tidak menguntungkan di pasar(Alshomrani \& Qamar, 2012).

Tabel 4.3

Analisis SWOT berdasarkan analisis komparasi dengan negara lain

\begin{tabular}{|c|c|}
\hline STRENGTH & WEAKNESS \\
\hline $\begin{array}{l}\text { 1. Landasan hukum yang kuat untuk } \\
\text { penerbitan Sukuk Negara. } \\
\text { 2. Komitmen Presiden bersama } \\
\text { industri untuk mengembangkan }\end{array}$ & $\begin{array}{l}\text { 1. Kurang berkembangnya pasar } \\
\text { Sukuk korporasi. } \\
\text { 2. Regulasi kurang komprehensif dan } \\
\text { disusun kasus per kasus. }\end{array}$ \\
\hline
\end{tabular}


pasar dan instrumen Sukuk melalui penyusunan Masterplan AKSI dan pembentukan KNKS.

3. Besarnya pangsa pasar Muslim dan potensi pasar ritel domestik dapat menjadi magnet bagi pasar keuangan syariah internasional.

4. Adanya trading platform instrumen SBN ritel dapat meningkatkan likuiditas pasar ritel, dapat pula dikembangkan untuk Sukuk Ritel.

5. DSN-MUI yang mendukung pengembangan keuangan syariah di Indonesia sangat responsif terhadap kebutuhan fatwa dan opini syariah.

6. Terdapat beberapa pilihan fatwa struktur Sukuk Negara untuk pembiayaan proyek, dapat diduplikasi untuk Sukuk korporasi.
3. Pasar ritel domestik belum cukup teredukasi, masih terbiasa dengan imbalan Sukuk dalam bentuk tetapdan adanya jaminan Pemerintah.

4. Pangsa pasar ritel yang besar masih membuat Indonesia sebagai konsumen dibandingkan menjadi leader maupun innovator.

5. Respon Pemerintah yang terkesan lambat dibandingkan dengan kebutuhan pasar, baik domestik maupun internasional membuat Indonesia kehilangan momentum.

6. Masterplan yang ada masih berorientasi pada pengembangan internal di pasar dalam negeri, belum terlihat upaya menempatkan Indonesia sebagai pemain di pasar internasional.

OPPORTUNITY

1. Kiprah Indonesia di pasar keuangan syariah internasional menempatkan Indonesia sebagai salah satu founder WIIB bersama dengan negara Islam besar lainnya.

2. Indonesia sebagai emerging market berpeluang mendorong pertumbuhan dibandingkan negara maju yang mulai jenuh.

\section{THREAT}

1. Pasar keuangan internasional bergerak pesat dengan berbagai inovasi instrumen.

2. Pasar keuangan internasional semakin menuntut adanya standarisasi penerbitan.

3. Semakin berkembangnya industri keuangan syariah, semakin besar ujian ketahanannya untuk menjadi 


\section{KESIMPULAN}

Indonesia memiliki banyak potensi untuk menjadi pusat Sukuk dunia namun diperlukan strategi yang komprehensif untuk mewujudkan ambisi tersebut terutama ketika dihadapkan dengan pasar keuangan internasional yang telah terstandarisasi namun bergerak cepat dan dinamis. Pangsa pasar ritel di Indonesia memiliki potensi besar, namun diperlukan strategi untuk menjadikan potensi ritel tersebut tidak sekedar menjadi sasaran konsumen negara lain. Setelah marketdriven berhasil mengawali kehadiran industri ini di Indonesia, sudah saatnya Pemerintah menentukan arah kebijakan dan strategi selanjutnya untuk menempatkan Indonesia tidak hanya sebagai pemain, namun sebagai pemimpin di industri keuangan syariah. Diharapkan KNKS dapat segera bekerja dan memberikan dampak nyata terhadap milestone industri keuangan syariah di Indonesia. Penelitian ini diharapkan menjadi sumbangan literatur yang dapat memicu penelitian lanjutan yang lebih komprehensif.

\section{DAFTAR PUSTAKA}

Abdullah, A. A., Yazid, A. S., Abdullah, A., \& Kamarudin, M. S. (2014). Risk in Funding Infrastructure Projects through Sukuk or Islamic Bonds. International Review of Management and Business Research, 3(2), 915-929.

Ainley, M., Mashayekhi, A., Hicks, R., Rahman, A., \& Ravalia, A. (2007). Islamic finance in the UK: regulation and challenges. Financial Services Authority. Retrieved from http://ara.assaif.org/content/download/279/3459/file/Islamic Finance in the UK.pdf

Alshomrani, S., \& Qamar, S. (2012). Hybrid SWOT-AHP Analysis of Saudi Arabia E-Government. International Journal of Computer Applications, 48(2), 1-7. https://doi.org/10.5120/7317-0065 
Asmat, S. (2014). Islamic Finance in the Western World: Development, legal regulation and challenges faced by Islamic Finance in the United Kingdom. Journal of Islamic Banking and Finance, 31(2), 91-108.

Audriene, D. (2017). Transaksi ORI Kini Bisa Dipantau Lewat ETP. Retrieved June 9, 2017, from

http://www.cnnindonesia.com/ekonomi/20170406120128-78-205402/transaksiori-kini-bisa-dipantau-lewat-etp/

Bappenas. (2015). Masterplan Arsitektur Keuangan Syariah Indonesia (Vol. December).

Bennet, M. S., \& Iqbal, Z. (2013). How socially responsible investing can help bridge the gap between Islamic and conventional financial markets. International Journal of Islamic and Middle Eastern Finance and Management, 6(3). Retrieved from internal-pdf://177.162.225.76/Bennet2013-How socially responsible investing.pdf

City of London Corporation. (2016). Globalising Green Finance: The Uk as an International Hub. Retrieved from http://greenfinanceinitiative.org/wpcontent/uploads/2016/11/Globalising-green-finance_AA3.pdf

Direktorat Pembiayaan Syariah. (2015). Sukuk Negara Instrumen Keuangan Berbasis Syariah.

Follan, P. (2016). Brexit and Islamic Finance - Challenge or Opportunity. Retrieved March 16, 2017, from http://www.the-ifes.org/2016/10/09/brexitand-islamic-finance-challenge-or-opportunity/

Haneef, R. (2009). From "Asset-backed" to "Asset-light" Structures: The Intricate History of Sukuk. ISRA International Journal of Islamic Finance, 1(1), 103-126.

Hasan, Z. (2010). Regulatory Framework of Shari 'ah Governance System in Malaysia, GCC Countries and the UK. Kyoto Bulletin of Islamic Area Studies, 2(March), 82-115. Retrieved from http://ssrn.com/abstract=2196825 Irfan, H. (2014). Heaven's Bankers Inside the World of Islamic Finance. Jaffer, S. (2016). Brexit and London's Role as an Islamic Banking Hub_ Is the Glass Half Empty, or Half Full. Retrieved March 11, 2017, from 
http://www.europeanfinancialreview.com/?p=8310

Latham and Watkins LLP. (2015). The Sukuk Handbook: A Guide To Structuring Sukuk.

London Stock Exchange. (2017). Accessing the Global Markets Through London, (December).

Maierbrugger, A. (2017). London keen to maintain role as Islamic finance hub. Retrieved March 11, 2017, from http://www.gulftimes.com/story/535511/London-keen-to-maintain-role-as-Islamic-finance$\mathrm{hu}$

Marwan, S. E. R. M., \& Adawiah. (2015). Sustainable and Responsible Investment (SRI): Trends and Prospects, (December). Retrieved from https://www.researchgate.net/publication/303985122_Sustainable_and_Resp onsible_Investment_SRI_trends_and_prospects

Najeeb, S. F., \& Vejzagic, M. (2013). Development, Growth and Challenges of Islamic Capital Markets: Comparative Insights from the Malaysian, Indonesian, United Arab Emirates and Brunei Markets. Journal of Emerging Economies and Islamic Research, 1(3), 1-38. Retrieved from http://www.jeeir.com/index.php/jeeir/article/view/71

Nangoy, F. F. (2016). Saudi Arabia to Join Turkey and Indonesia in Infrastructure Islamic Bank. Retrieved June 9, 2017, from

http://www.reuters.com/article/us-islamic-finance-saudi-idUSKCNOYE0U1

Nizami, S. M. (2011). Islamic Finance: The United Kingdom's Drive to Become the Global Islamic Finance hub and the United States' Irrational Indifference to Islamic Finance. Suffolk Transnational Law Review, 34.

Securities Commission Malaysia. (2011). Capital Market Masterplan 2. https://doi.org/10.1017/CBO9781107415324.004

Setkab. (2016). Punya Potensi Besar, Presiden Jokowi Ingin Jakarta Jadi Pusat Keuangan Syariah Internasional. Retrieved June 10, 2017, from http://setkab.go.id/punya-potensi-besar-presiden-jokowi-ingin-jakarta-jadipusat-keuangan-syariah-internasional/

Sparkes, R. (2002). Socially Responsible Investment: A Global Revolution. 
Electromagnetic Waves and Antennas (Vol. 1). England: John Wiley \& Sons. https://doi.org/10.1016/S0969-4765(04)00066-9

Waluyanto, R. (2009). Pengelolaan Utang Pemerintah, Surat Utang Negara dan Surat Berharga Syariah Negara, dan Pinjaman Luar Negeri. In A. Abimanyu, Anggito; Megantara (Ed.), Era Baru Kebijakan Fiskal: Pemikiran, Konsep, dan Implementasi (Vol. 1, p. 631). Jakarta: Penerbit Buku Kompas. https://doi.org/10.1016/S0969-4765(04)00066-9

Wang, D. T., Zhao, S. X., \& Wang, D. (2007). "Information hinterland" - A base for financial centre development: The case of Beijing versus Shanhai in China. Tijdschrift Voor Economische En Sociale Geografie, 98(1), 102-120. https://doi.org/10.1111/j.1467-9663.2007.00379.x 